DOI https://doi.org/10.18551/rjoas.2017-06.10

\title{
PLANNED AND MARKET MODELS SYMBIOSES IN PRIMARY SECTORS OF NATIONAL ECONOMIES
}

\author{
Prilukov A.N., Candidate of Sociological Sciences \\ Far Eastern Branch, Mining Institute of Russian Academy of Sciences, Khabarovsk, Russia \\ E-mail: a prilukov@mail.ru
}

\begin{abstract}
Proceeding from the materialistic understanding of human history, analysis results are presented in the article, based on the widely known Socio-Economic Formations conception. Main conclusion, which arises from this analysis, consists in assertion of fundamental role that planned and market models symbioses play in most national economies, characterized by their substantially developed primary sectors. Major other conclusions arrived at in the wake of the analysis are formulated briefly as follows: (1) all existing economic entities in national economies based on their primary sectors are essentially mixed; (2) according to this, national economies are proposed to be classified into three major categories - plan oriented (POE), virtually balanced (VBE), and predominantly market-oriented (MOE); (3) MOE and VBE economy types are estimated as prevailing now, while VBE and POE are presented as presumed strategic World's economic development directions; (4) "Plan vs. Market" economies controversy is asserted to be largely irrelevant to "Capitalism vs. Socialism or Communism" one, which is determined mainly by dominant surplus value appropriation mode; (5) both plan and market-oriented managerial mechanisms are rendered as essentially intrinsic and virtually indispensable for stable functioning and successful development of modern World's economy.
\end{abstract}

\section{KEY WORDS}

Materialist understanding of history, socio-economic formation, primary economic sector, economic models symbiosis, mixed economy, plan-oriented economy, market-oriented economy, virtually balanced economy.

The research described in the article was initiated at late 1980-s and is up to now continuing. Its underlying methodological idea is well-known Materialist Understanding of History, according to which all major historic transformations to large extent occur independently of humans' will and are even not always fully recognized by respective populations [1-3]. Within this idea the Socio-Economic Formation (SEF) conception, developed in its profound features by K. Marx, F. Engels, and V.I. Lenin, is most outstanding [4-6]. SEF conception describes political-economic structure of both previous and existing societies, whose essential core is presented as appropriately matched combination of Productive Forces and corresponding Socio-Economic Relations' patterns that determine social system functioning. Historic replacement of one SEF type by another is believed to be governed by objective mechanisms mostly insubordinate to the individuals' will.

All along the SEF theory existence it was exposed to various sorts of apprehensions and criticisms. In former USSR and modern Russia these assaults have been notoriously persistent at late 1980-s and became virtually deteriorative in the last decade of XX century [7-8], when Russia was painfully experimenting with hastily and recklessly adopted doctrine of so-called Chicago School of Economics. This period was marked by rapidly collapsing domestic economic integrity, which has been eventually reversed to upward trend only after Russia has switched-over to nation-oriented course beginning at early 2000 -s.

One of the major challenges concerning SEF theory is that none of these formations has been ever seen in "pure" form. Clear response to this claim has already been done in classics' works. Widely known, for example, is Lenin's remark, asserting that all real SEFs are inevitably mixed as far as among other elements they contain within themselves the remnants of previous formations and prerequisites of future ones. Besides, historic 
materialism classics more than once underlined substantially abstract nature of SEF notion, as well as all other scientific notions, theories, models, and laws. Apart from Marxism classics, there are great deals of publications, illustrating this close to universally accepted maxim. With respect to SEF theory it is clearly expressed, for example, in [9], where author in addition stresses the need for every scientific branch to as much as possible streamline its theories, replacing abstract scientific terms by descriptions of their manifestations in practice.

While SEFs are considered to be complex multifaceted political and socio-economic phenomena, appropriate to certain Valuables Production and Acquisition Modes, their economic essence is expressed by various more or less formalized and hence relatively simple models. Two widely known and frequently mentioned modern economic models are Planned and Market ones, which by consensus correspond respectively to Socialist and Capitalist SEF kinds. In more detailed classification schemes intermediate, transitional, and collateral model varieties are being singled out. For example, French scholar Michel Albert in his popular "Capitalism versus Capitalism" monograph distinguishes two capitalist economic models: Anglo-Saxon (liberal) and Rhine (non-liberal) capitalism types. According to this author, Anglo-Saxon model, represented by USA, Great Britain, Canada, Australia, New Zealand, Ireland, et al, is based on markets' leading role, individualistic ideology, and deregulation. In Rhine model, represented by Germany, Japan, Scandinavian and other European countries, alongside market orientation, noticeable roles are assigned to state organizations, business associations, trade-unions, business networks, and other social structures. This model is characterized by presence of mechanisms that provide higher levels of individuals' social security, expressed in tangible elements of collectivism, paternalism, and solidarity [10-11].

According to other existing classifications, specified by amounts of state participation in guaranteeing social security and collective patterns of intracorporate management, such countries with lengthy market traditions as Australia, Japan, Scandinavian, and some others are frequently rendered as virtually socialist.

One more criteria set for economic models differentiation are means of production ownership patterns. As is asserted in [12-13], on the background of modern economies' deepening complexity ever more spheres are arising, where market motivation is either drastically limited or simply impossible. Besides, modern market models are increasingly becoming based on compositions of individually-private, partnership-private, joint-stock, state, and mixed ownership patterns, which urge further economic models diversification.

Growing number of publications are up to now devoted to dual-core or mixed models, which join together planned and market economic patterns. Most graphic demonstration of such models' virtues is China's experience, which due to this model's adoption in historically short period managed to rise from almost scratch to one of the World's major superpowers. An example of simple and at the same time effective mechanisms of mixed models realization is believed to be public-private partnership (PPP) [14]. Various Russian authors assume that PPP by its enhancing the efficiency of interaction between government, private business and civil society ensures economic growth and socialization of public relationships, as well as helps to solve some other major problems of domestic economy [15-17].

Substantial interest is provoked by publications of those authors, which propose personal variants concerning development and realization of new economic models, presumably more progressive compared to existing ones and simultaneously void of their flaws. For example, prominent adherent of Marxist legacy Harry Ratner critically juxtaposes two theoretic works: of A. Nove "The Economics of Feasible Socialism" (1983) and P. Devine "Democracy and Economic Planning" (1988) [18]. Whereas both authors essentially agree in criticizing Marx's theory for its outdated character and lack of practical implementations, they substantially differ in prognostic assessments and proposals. The first advocates amalgamating both plan and market mechanisms and blending opposing to each other forms of ownership and control. The other rejects Nove's "market socialism" and proposes instead a model of planning, which he calls "negotiated coordination", that envisages employees' participation in decision-making at all organizational levels. 
It's worth mentioning some recent publications in Russian Journal of Agricultural and Socio-Economic Sciences, whose topics closely relate to those discussed above. One of them justifiably reminds of the controversies, unceasingly raging on the question of capitalism vague future and its pending necessity to give way to more balanced and just social organization [19]. The other attracts particular attention by its innovative idea of economy's "market versus plan" orientation measurement with the help of special index, proposed by the authors, whose quantitative value reflects economic activity's direction, determined to large extent by the country's legislation [20].

Article's author contribution to popularizing and development of ideas being discussed is presented in personal monograph [21] and some other author's publications [22-30].

Primary sectors' specifics in national economies. As is demonstrated in [30], primary sector of the World and many national economies is mainly represented by two productive complexes - Agro-Industrial and Mineral (Fig. 1). According to Russian long-standing tradition both complexes are embraced by a wide and versatile notion «Prirodopol'zovanie» (Nature Husbandry). Being akin to its English language version Natural Resources Management (NRM), Nature Husbandry notion is more comprehensive. Alongside with managerial functions it covers also social, demographic, ecologic, and other aspects of natural resources rational acquisition and utilization.

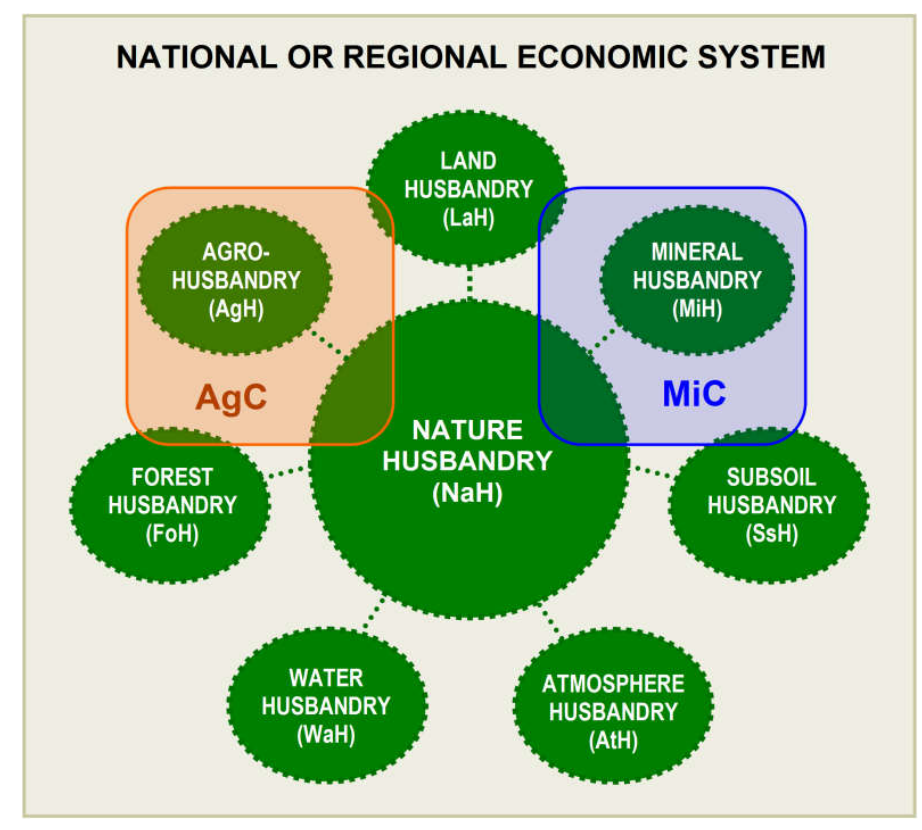

Figure 1 - Agricultural $(\mathrm{AgC})$ and mineral $(\mathrm{MiC})$ complexes' places in national or regional Nature Husbandry systems [30]

In addition to formal attribution to the same category, both complexes are coupled by a number of common features. It's worthwhile mentioning here some of them.

1. $\mathrm{AgC}$ and $\mathrm{MiC}$ functioning is highly dependent on peculiarities and freaks of natural environment.

2. Both complexes are characterized by invariable attachment of production facilities to locations endowed with appropriate natural resources and other prerequisites.

3. Natural resources exhaustibility and only partial or even totally absent renewability are almost equally characteristic to both complexes.

4. Both complexes are subjected to tendencies identical or similar in their manifestations - rising intensification of production processes, widening their scales and territories involved, etc.

5. Functioning of both complexes is coupled with high impacts, mostly negative, at natural and residential environments. This entails substantial efforts and resources, being allocated for neutralization or compensation of these impacts manifestations and outcomes. 


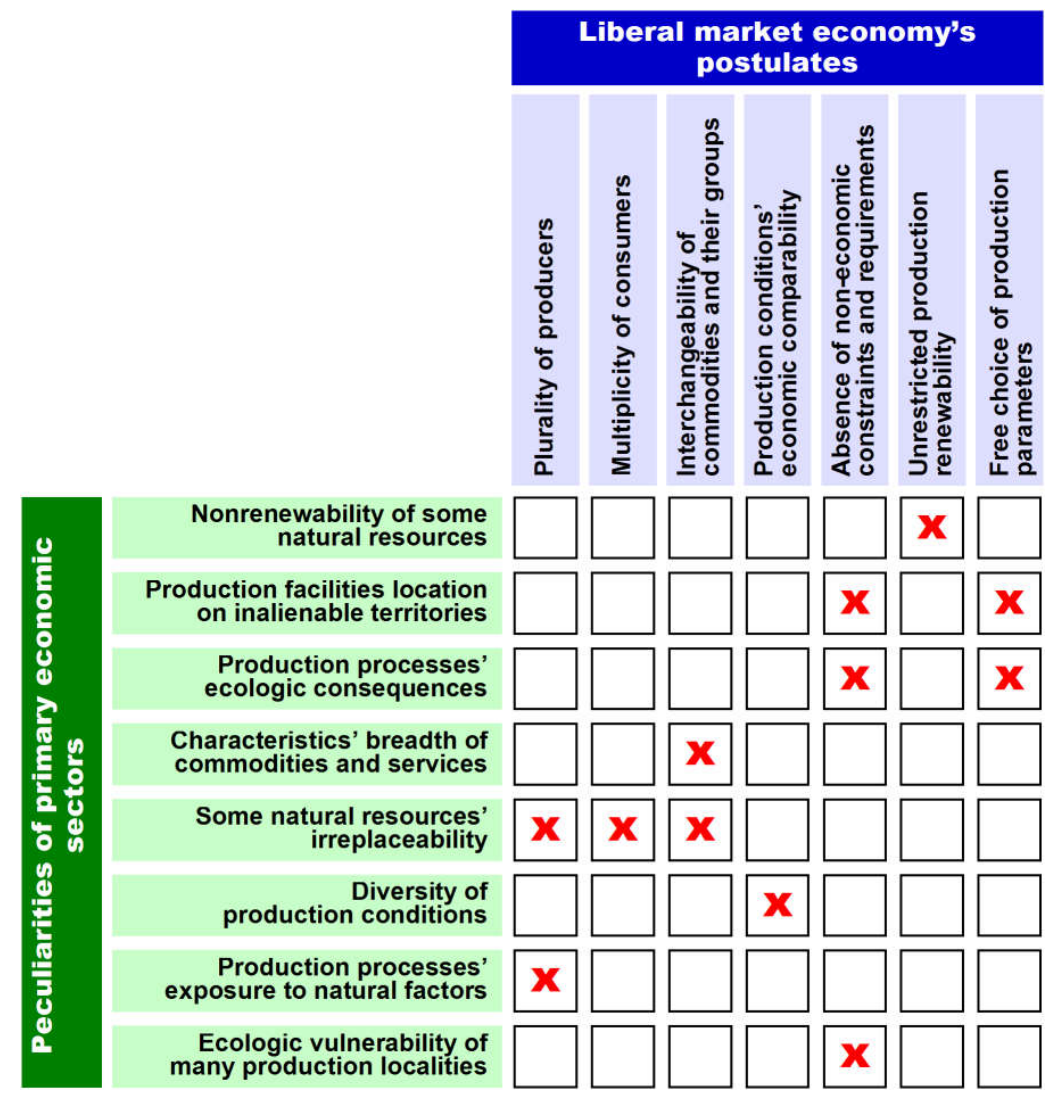

Figure 2 - Discrepancies between primary economic sectors peculiarities and liberal market economy's postulates [22; 23]

Attention is attracted here by the fact that all listed complexes' peculiarities substantially discord with initial requirements inherent to canonic liberal economy's model. For example, exhaustibility and nonrenewability of some major natural resources (item 3 of above enumeration) forces governments to introduce limitations or fully prohibit their industrial development and/or export. Complicated accessibility and poor or totally absent infrastructural adaptation of the territories being developed, as well as their intensive use for residential, recreational, nature conservation, and other socially meaningful purposes (items $1,2,5)$ leave as potentially viable producers of agricultural and mineral-based commodities only those rare firms which have required financial, material, technical, and other resources, and besides necessary experience in appropriate activities.

Listed characteristics substantially diverge with liberal economic model's postulates, which stipulate presence of many producers competing between themselves; comparability of starting and other economic conditions of their activities; interchangeability of market commodities, including those belonging to different tradable groups; conditions availability for free movement of production facilities, commodities, labor force; non-economic leverages absence with respect to producers and consumers; unlimited production renewability.

Some of mentioned $\mathrm{AgC}$ and $\mathrm{MiC}$ peculiarities that are not antagonistic with liberal economic model's requirements nevertheless impede its full-fledged employment because they dictate non-economic criteria and mechanisms utilization for productive processes management. For example, natural resources localization on inalienable territories urges agrarians and miners to engage with production assets proprietors, most often state or municipal governments, in particular relations that are not envisaged by liberal economic model. Similar effects are provoked by the production processes negative ecologic impacts, diversity of natural environment conditions, complicated accessibility and poor infrastructural procurement of the territories being developed. A simplified pattern of production processes peculiarities divergence with respect to liberal economic model requirements is shown at Fig. 2. 
Institutional and functional structures of mineral resources management. While comparing organizational patterns of Mineral Resources Management (MRM) in various countries that in substantial quantities produce and/or consume mineral resources and at the same time belong to different Socio-Economic Formations, their significant similarity aptly reveals itself. Particularly, in developed countries that have predominantly Market-Oriented Economies (MOE) MRM is organized in significantly the same way that in former or modern states, characterized by their Plan-Oriented Economies (POE), among them those that position themselves as Socialist.

At the same time MRM organizational structures of various countries noticeably differ according to their affiliation with concrete SEF types. For example, mineral resources management in plan-oriented as opposed to market-oriented countries is characterized by prevalence of administrative management mechanisms over economic ones. Institutional, infrastructural, and ideological mechanisms of commodity-money relations there are less developed. Besides, different elements of MRM organizational structure are not completely accommodated to dynamically varying economic environment.

Most compatible with market economic model is mining of widespread minerals which is performed without use of complicated technological processes, huge mechanisms, and other bulky production facilities. But even in those circumstances, placer and underground mining of such valuable minerals as gold, platinum, precious stones etc., carried out by individuals and "wild" miners brigades, often rapidly acquires criminal forms and happen to be forcefully liquidated by local or central governments.

Specifics of large-scale industrial minerals production entail that main mineral resources producers and consumers - large and medium-sized firms and corporations cannot claim to be full-fledged embodiments of market model. Suffice it to say that in intracorporate relations, where affiliated firms and hierarchically subdominant structural divisions participate, principles and rules of undivided authority, beforehand planning, and strict plan realization control are overwhelming. At state level all this is characteristic to planned economy. Nevertheless, firms and corporations, large among them, outwardly act as rightful participants of market relations in their modern, substantially complicated form compared to canonic market model. Market status of these economic subjects is expressed in their administrative independence; self-reliant choice of corporate activities, including their strategic and tactical directions; participation in transactions at national and World markets of assets, information, raw materials, finances, labor force, commodities, and services.

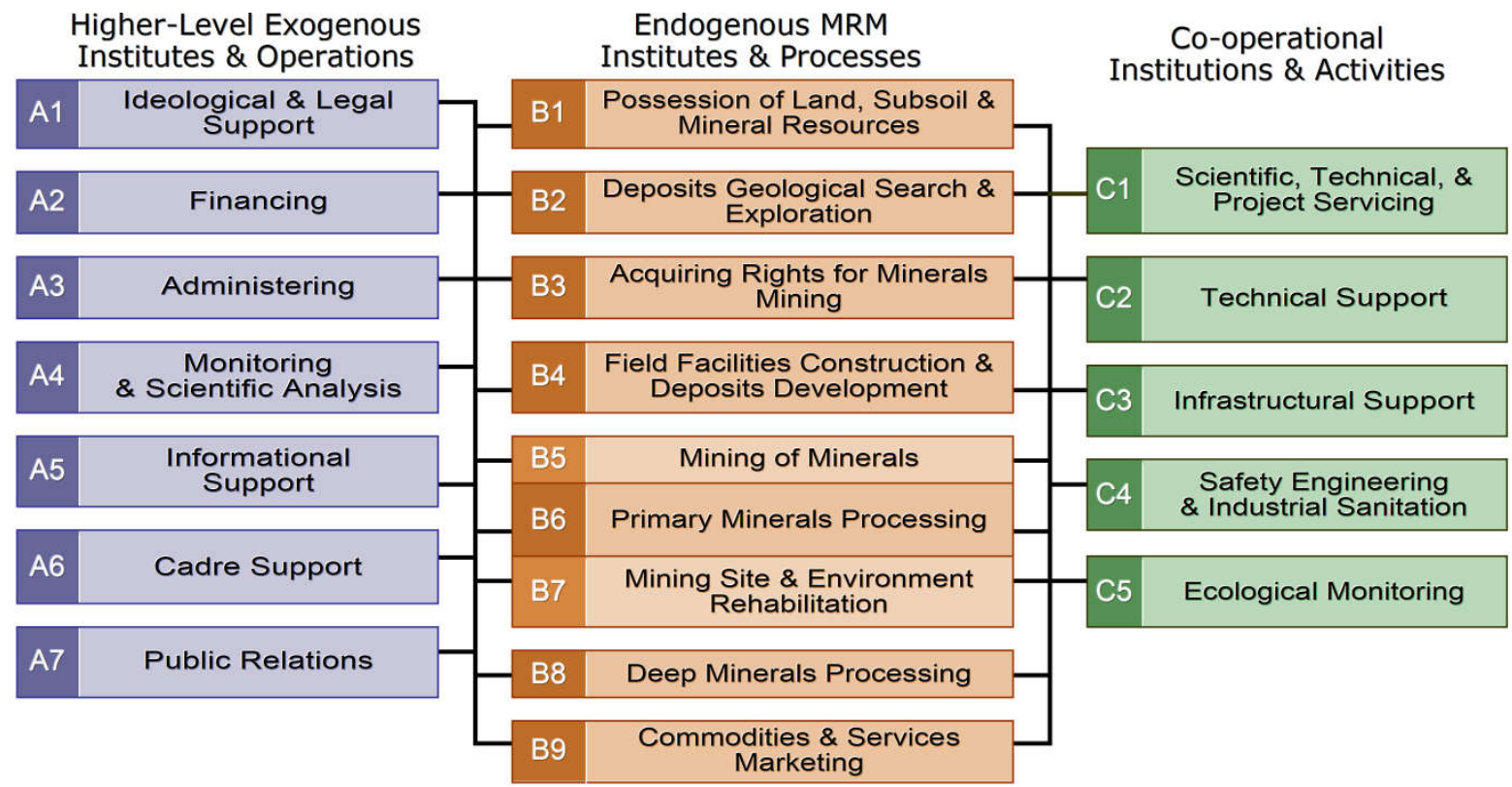

Figure 3 - Institutional and functional MRM-model at corporate and adjacent organizational levels $[21 ; 22 ; 28]$ 
Formalized description of MRM organizational structure is complicated by frequent and sometimes radical changes occurring there. In market-oriented economies some changes are determined by small and big crisis cycles. Other current changes are conditioned by global tendencies of natural resources exhaustion; World's political and economic topologies evolution; economic, scientific, technical progress; and many others. In their turn, global and local cyclic variations of market conditions entail recurring mutual interchanges between market (monetary) and planned (socially oriented) paradigms. Nevertheless, organizational forms, which are determined by production technologies and levels achieved in economic processes management, during long time periods retain their main features that can be illustrated by Fig. 3 schematic diagram.

At the model's core lies traditional-conventional differentiation of activities pertaining to extraction, processing, marketing, and industrial utilizing of mineral resources. This differentiation is reflected in industrial branches, territorial, and institutional MRM stricture at its various organizational levels.

It's worth to note that model's central section, especially blocks B2, B4-B8, are playing almost identical roles in countries belonging to different SEFs, as far as these roles are rigidly determined by existing methods of raw materials industrial development. Nevertheless, at close look some distinctions pertaining to competing socio-economic systems are also revealed. For example, block Possession of Land, Subsoil, and Mineral Resources (B1), whose functions in state-run economies are significantly reduced, in marketoriented economies acquire prime significance. There this block is represented by real private and public owners, which possess, dispose, and/or personally utilize land, subsoil, and respective assets. These property elements are supplemented by traditional social relations and timely upgraded legislation that functions on the basis of adopted realization mechanisms. Natural resources industrial development in such countries most often begins at the owner's decision to practically implement his possessions, after which certain actions are undertaken stipulated by existing legislation and traditions - land and subsoil assets competitive marketing, appropriate companies inviting for geologic prospecting, exploration, designing, mining, processing, logistics, and so forth. In plan-oriented economies similar actions are typically initiated at higher organizational levels and reach production units in the form of adopted projects and plans, usually coordinated with other executive organizations.

Demonstrable differences exist between functions peculiarities, their distribution among MRM-model's blocks (Fig. 3), as well as their institutional realization throughout hierarchical structures of both plan and market-oriented economic systems. In author's publications [21$25]$ these similarities and deviations are specified in substantial details.

Similarities and watersheds between plan and market-oriented economies. One of key roles in plan versus market-oriented economies division lies in their hierarchical organizational structures. In both countries' groups functions of natural resources management are almost uniformly distributed among all existing organizational levels, including transnational one. At the same time some principal distinctions do exist. With respect to mineral resources management one of them consists in practically total absence of its individually-private form of realization in plan-oriented economies, whereas in marketoriented countries such organizational forms are practically commonplaces at all managerial levels. This manifests itself in that even vast territories together with natural resources located within their boundaries happen to belong to individuals which dispose of these assets at their personal will. Unlike market-oriented economies, where functions of resources ownership and disposal, financing, administering, cadre support, scientific analysis and aligned with it control (fig. 3) are, as a rule, prerogatives of companies themselves or close to them structures at the same organizational level, in plan-oriented economies these functions are typically distributed all along "managerial vertical line".

Substantial difference between two compared economy types lies in the absence of sharp demarcation lines among sectors and branches of market-oriented economies, which is characteristic to former socialist and to some extent modern POE countries. Companies' and corporations' specialization in market oriented economies is realized mostly according to their "know-how" - types of activities that ensure companies' highest competitiveness in 
existing economic environment. Proceeding from this, companies emerge which are specialized, for example, in earth-moving, construction, mining, processing, logistics, legal consulting, and so forth. Accordingly, a company that is specialized in earth-moving operations may occasionally conclude contracts with whatever firms and objects that provide its production facilities utilization irrespective of these objects' pertaining to different economic branches.

Peculiarities of natural resources management in market-oriented economies are frequently demonstrated in production diversity, expressed in wide ranges of companies' activities types and spheres and revealed in their simultaneous or alternating operations. Cultivated and constantly kept updated readiness of large companies to switch onto new activities types and wide ranges of their applications serve in market conditions as sufficiently stable guaranties of companies' survival capabilities, competitiveness, and operational stability.

Proceeding from the experience of such developed MOE countries' as Australia, Brazil, France, Germany, UK, USA, et al it follows that national governments' participation in economies' primary sectors functioning is by no means confined to relatively short periods of economic crises and post-crises recoveries, but persistently continues even in stable economic development conditions. It is exposed particularly in balanced interaction organization between primary and other sectors of national economies; creation, maintaining, and development of transport, residential, social, and other infrastructure types at primary sector objects localizations; rights and interests of primary sector producers' advocating at international markets etc.

In most national governments of traditionally market-oriented countries there are divisions whose functions encompass key management directions of production and commerce. These in particular are ministries, departments, committees of agriculture, minerals mining and utilization, fossil fuels and energetics, environment protection and development, etc. However, those divisions' functioning doesn't include direct administering of companies' and production/commercial units' current activities, excluding those units which are directly affiliated with appropriate governments.

Statics and dynamics of plan vs. Market models symbiosis. In above discussion it was demonstrated that with respect to economies' prime sectors the plan and market-oriented economic mechanisms act rather jointly than unrelatedly. Besides, natural resources management, being realized within competing socio-economic systems, continues to develop upon mutually complementary composition of structural elements belonging to compared economic models.

However, it will be deeply erroneous to contend that modern economy's structure is presented by certain combinations of only two opposing economic models. Quite obvious are presented their elements, not exclusively pertaining to either of the models and instead actually being invariant to both of them (Fig. 4).

In accordance with fig. 4 concise definitions, among factors and tendencies invariant with respect to compared economic models and roughly equally characteristic to both of them there are processes, connected with diversifications and/or consolidations of produced services and commodities, optimization of processes aimed at production costs reducing and goods quality enhancement, and others.

At the other hand, certain varieties of intensive NRM processes are specific primarily within market-oriented economies and nonrelevant to their plan-oriented versions or exist there in trimmed and underdeveloped variants. These are widely spread banking operations and services, massive expansion of operations with equities, free exchange operations with stocks and commodities, operational assets purchases and sales performed by enterprises etc.

As prerequisites and visual proofs of economy's market-orientation strengthening can be considered companies' denationalizations and privatizations. Among other evidences of the same kind are sales of state-owned share packages; development of social, transport, and informational infrastructures at regional and federal levels; relaxation of government control over transborder operations; activities aimed at companies ongoing capitalization; 
access alleviating with respect to economic, geological, and other information, necessary in companies' production and commercial activities; informational transparency enhancement concerning NRM subjects' functioning. Toward opposite results lead actions, connected with companies' nationalizations, strengthening of state participation in companies' equity capital management, confidentiality regimes toughening with respect to corporate information, and others.

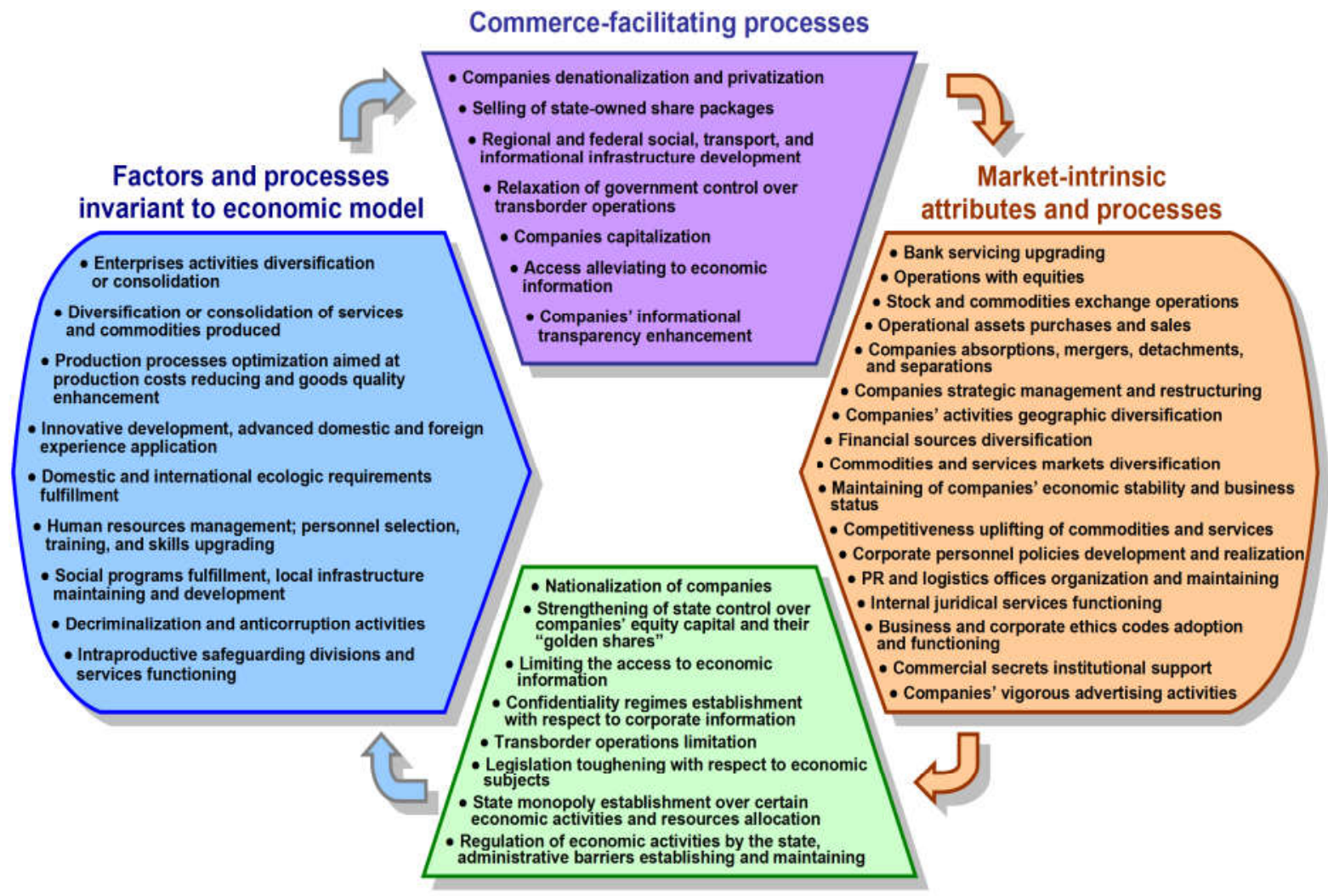

Factors of decommercialization

Figure 4 - Interrelations between factors and processes specific and invariant to planned/market economies' controversy [22]

Above specified multidirectional actions and events have also been traced at corporations and enterprises levels. At certain research stages chronologies were composed and arranged, relating to sufficiently lengthy periods and reflecting main actions performed by managements of some major Russian and multinational companies.

As an example, at fig. 5 statistical digest of one such chronology is presented. It depicts squeezed and reorganized chronological statistics of PJSC "MMC Norilsk Nickel" major actions and events [31], beginning from its registration within Russian Federation jurisdiction at 4.07.1997 and ending with agreement signing at 20.11.2006, concerning OM Group Inc's nickel business purchasing. Registered actions and events are presented in generalized form, which reflects their substantive specifics and enables classification according a few major consolidated categories.

Attention at fig. 5 is attracted by significantly prevailing amounts of events and related company's actions aimed at diversification of its various activities areas, and also by its widening and deepening presence in World's economy as active market relations participant. Most significant actions, connected with swapping of property forms, have been represented at analyzed period by four events, directed at public assets privatization in company's favor (item 1.1), whereas at the same time none of the reversely directed events has been fixed (item 1.2). This, as well as other similar comparisons, testifies in favor of company's steady adherence at that time to chosen course toward its market status upholding and strengthening. 


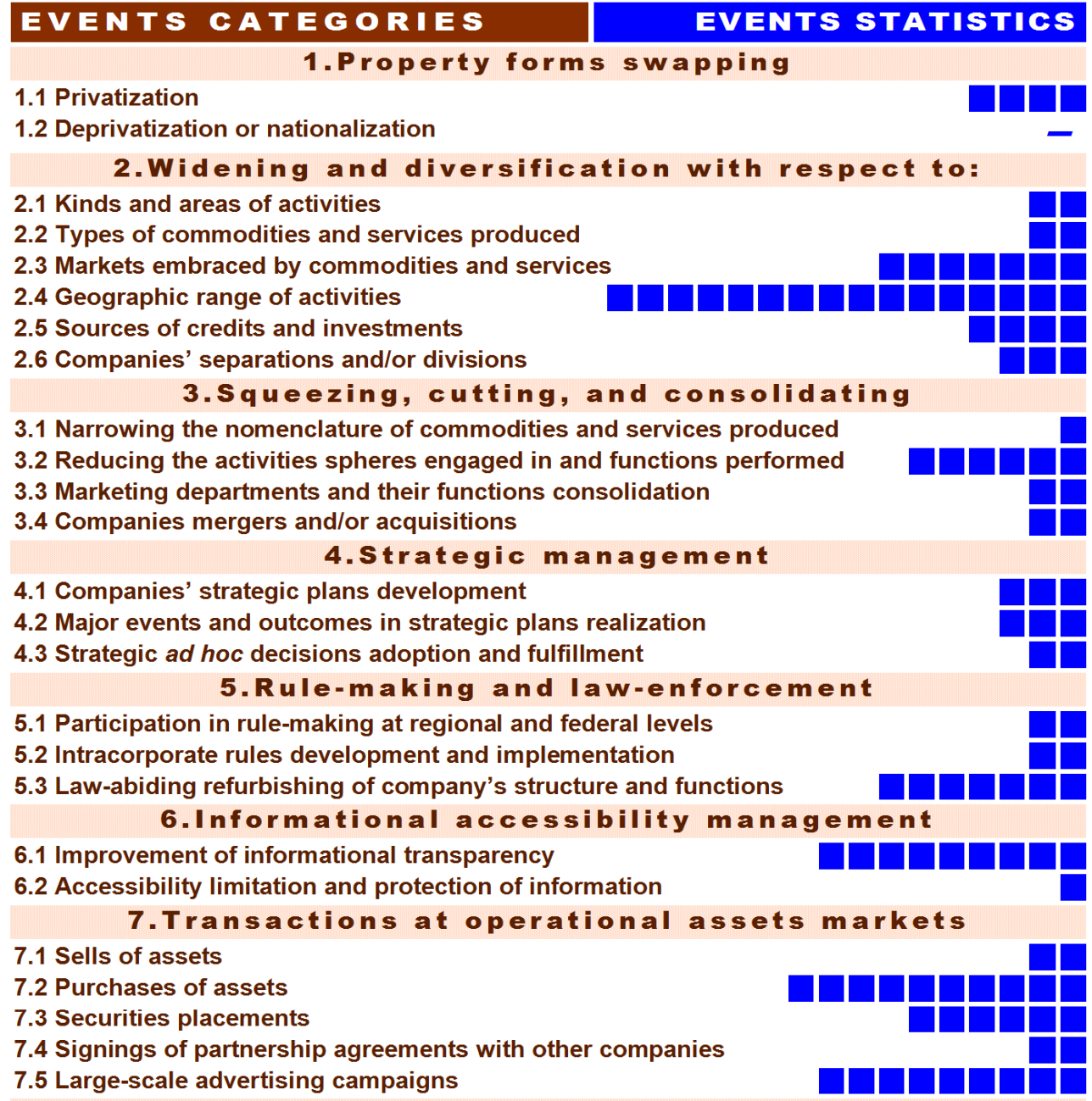

$$
\text { 8. Restructuring and other major actions aimed at: }
$$

8.1 Intracorporate processes optimization

8.2 Production expenses reducing and its profitability raising

8.3 Company's publicity widening

8.4 Company's competitiveness boosting

8.5 Company's financial stability strengthening

8.6 Crime and corruption eradication in company's activities

9. Company's social profile maintaining and widening

9.1 Workforce policy systemic development and realization

9.2 Assistance and catering for former company's employees

9.3 Social programs realization in company's location areas

9.4 Local communities development promoting

9.5 Large-scale charitable functions performing

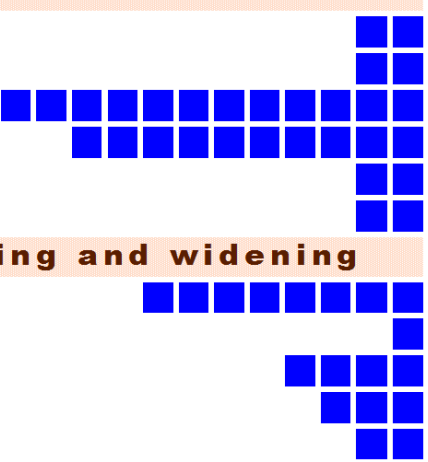

Figure 5 - Statistics of PJSC "MMC Norilsk Nickel" major corporate activities and events in 1997-2006 fiscal years [31]

Generally, MMC Norilsk Nickel activities at analyzed period were characterized by corporation's clearly expressed commitment to completely integrate into market economy's environment, which was profoundly stimulated then by steady World economic development, prior to breaking out in 2008 of worldwide financial-economic crisis.

\section{CONCLUSION}

According to one of the confronting ideas, persistently advertised by unlimited liberal market advocates, any direct government meddling into companies' activities immediately or ultimately, but inevitably leads to slowing its economy's development and dropping down of its attained level. Their adversaries quite reasonably contend that all-embracing liberal 
markets, first, never have been seen in history and, second, once being realized will unavoidably lead to destructive economic depressions, sectoral and overall crises, commercial, financial, inter-corporation and full-fledged wars, as well as other well-known and not less significant economic, social, and ecologic disasters.

Meanwhile, current popular apprehensions concerning market versus planned economic models' alternatives are as a rule far from adequate. For example, most modern economically developed countries, traditionally positioning themselves as "free market worship models", are once and again demonstrate their far from market behavior by applying various politically motivated sanctions against their unfavored market competitors, introducing restricting and forbidding measures concerning chosen groups of commodities and countries, ousting from their own territories toward so-called "third-world" countries those production facilities and whole industrial branches that are less profitable, more laborintensive, and ecologically unsafe.

As far as primary economic sectors are concerned, practically in all appropriate countries, including market-oriented ones, states as a rule substantially intrude into market players' functions. Specifically, in governing bodies of above-mentioned countries at different administrative levels there are divisions, vested with managerial functions with respect to productive and commercial activities in various economic spheres. Most Western countries, unshakably accustomed to their self-esteemed market posture, financially and otherwise support their primary economic sectors, which takes shape in widespread patronizing or outright financially subsidizing their agricultural or mineral complexes, and so forth.

Two economic models effective joint functioning is clearly confirmed by China, Belarus, and other countries that adopted and are practically implementing the idea of "one state two systems". In China, for example, this idea, alongside with socialist-market economics theory, became one of major components during national economy reforming in "socialism with China's specifics" direction [32, p.19]. Since the turn of the century up to now it procured 7-fold growth of China's economy, converting it into second most powerful World's economies.

One more graphic proof of plan and market economic models dynamic symbiotic coexistence are, perhaps, multidirectional property forms swappings that in last decades became quite common, particularly in mining industries of such countries, as Great Britain, Germany, SAR, and others. It's worthwhile to note that these swappings in most cases were made in accordance with appropriate governments' decisions, based on preliminary exhaustive calculations and wide public discussions. Excluding former Socialist countries and so called Peoples Democracies, swappings' directions were both "market-wise" as well as "plan-wise". There were some cases when opposing swapping directions sequentially changed places.

Confining analysis scope to those countries whose economies substantially rely on primary sectors, research results can be briefly expressed as follows.

1. Both market and plan economic models in their essence are theoretic abstractions, which were never seen in "pure" forms and are practically embodied now in multiple "meshed" realization versions that combine in various proportions universal and specific mutually opposing managerial mechanisms. In rough accordance with "market" versus "planoriented" mechanisms proportion, real economic entities at national, regional, or corporate levels are skewed predominantly towards "market" or "plan" overall economic patterns.

2. Existing national economies, at least those substantially dependant on their primary sectors, are without any exceptions essentially mixed ones, combining in various proportions specific plan and market-oriented managerial mechanisms. According to this, national economies are proposed here to be classified onto three main categories: predominantly or at least intentionally plan-oriented economies (POE), virtually balanced economies (VBE), and traditionally or circumstantially market-oriented ones (MOE).

3. According to rough preliminary estimates, MOE and to some extent VBE model types are most common in modern national economies. At the same time overall strategic development is being directed now to VBE and ultimately POE types. The later is particularly 
necessitated by rapid and aggravated natural resources depleting, incompatible with the World's dashing population and consequent consumption growths.

4. "Plan vs. Market" economies controversy is to large extent irrelevant to "Capitalism vs. Socialism or Communism" one. The later is determined now, as it was in previous centuries, by the mode the surplus value, developed in production and commercial processes, is appropriated, distributed, and ultimately used. In both modern POE and MOE countries there are vast varieties of elaborated mechanisms, to large extent capable to properly arrange surplus value management, thus minimizing existing distance between two competing economic systems and enabling their smooth joint transition into forthcoming socio-economic formation, more socially just and simultaneously economically effective and stable.

5. As far as national primary economic sectors are concerned, both plan and marketoriented managerial mechanisms there are not only competing, but essentially serve as inseparable intrinsic parts of sectors' inner economic structures, enabling their stable functioning and successful development in competitive market environment. Consequently, one of the main tasks of every substantially developed company's and, moreover, national economic managements are timely adjustments of their plan-to-market mechanisms' balances so that they precisely and dynamically fit to current and anticipated forthcoming economic fluctuations and drifts.

\section{REFERENCES}

1. Konstantinov F.V., Glezerman G.E., Gak G.M., Kammari M.D., Hrustov F.D., Judin P. Istoricheskij materializm. M.: Gospolitizdat, 1950. - URL: http://istmat.info/node/302

2. Derbov L.A. Vvedenie $v$ izuchenie istorii. - URL: http://www.opentextnn.ru/history/?id=2632

3. K. Marx, F. Engels, V.I. Lenin. O dialekticheskom i istoricheskom materializme. - M.: Politizdat, 1984. - URL: http://marxistphilosophy.org/diahismat/index.htm

4. Jenciklopedija marksizma. Obshhestvenno-jekonomicheskaja formacija. - URL: https://www.esperanto.mv.ru/wiki/Марксизм/Общественно-экономическаяФормация

5. Kochetova L.M. Kategorija «obshhestvenno-jekonomicheskaja formacija» v rabotah Karla Marksa 40-h i 50-h godov XIX v. - URL: http://dlib.rsl.ru/loader/view/01000035876?get=pdf\&usg=AFQjCNG9WdxoxurECWIDOfiX qQ9LFPJtvw

6. D'jachenko V.I. Marksistskaja teorija obshhestvenno-jekonomicheskih formacij. - URL: http://www.opentextnn.ru/history/?id=2632

7. Katasonov V.Ju. Kritika materialisticheskogo vzgljada na obshhestvo i istoriju. - URL: http://pereprava.org/knowledge/3113-kritika-materialisticheskogo-vzglyada-naobschestvo-i-istoriyu.html

8. Semjonov Ju.I. Marksova teorija obshhestvenno-jekonomicheskih formacij i sovremennost'. - URL: http://scepsis.net/library/id_120.html

9. Semjonov Ju.I. Linejno-stadial'naja interpretacija unitarno-stadial'nogo podhoda $\mathrm{k}$ istorii i ee nesostojatel'nost'. - URL: http://iptie-rudn.ru/akademiilestestvoznanie/astrologiya/linejno-stadialnaya-interpretaciya-unitarno-stadialnogopodhoda-k-istorii-i-ee-nesostoyatelnost/

10. Shevchuk A.V.. Social'naja rol' biznesa v modeljah korporativnogo upravlenija. - URL: http://spero.socpol.ru/docs/spero_no2_shevchuk.pdf

11. Shevchuk A.V. Modeli «rynochnoj» jekonomiki: social'nye cennosti, ideologii, instituty. URL: http://elibrary.ru/download/89271523.pdf

12. Porohovskij A.A. Jepoha smeshannoj jekonomiki: rost ob\#joma rynochnyh operacij usilivaet finansovuju rol' gosudarstva. M., 2012. - URL: http://do.gendocs.ru/download/docs-74633/74633.doc

13. Porohovskij A.A. Sovremennaja rossijskaja rynochnaja model': jekonomicheskie i nejekonomicheskie faktory realizacii. - URL: http://www.econ.msu.ru/cd/202

14. Zeldner A.G. Formirovanie smeshannoj jekonomicheskoj sistemy kak uslovie 
ustojchivogo razvitija Rossii. - URL: http://dpr.ru/journal/journal_40_5.htm

15. Zeldner A.G. The partnership of government, business and society in a mixed economy. - URL: http://econpapers.repec.org/paper/ruawpaper/y_3a2010_3azeldner_3a1.htm. URL:

16. Zakimatov G.V. Dvuhsektornaja jekonomika - vyhod iz krizisa. - URL: http://old.nasledie.ru/oboz/N06_00/06_16.HTM

17. Zakimatov G.V. Dvuhsektornaja jekonomika: vospominanie o budushhem. - URL: http://sr.fondedin.ru/new/fullnews arch to.php?subaction=showfull\&id=1314789514\&arc hive $=1314876917 \&$ start_from $=\&$ ucat $=14 \&$

18. Ratner H. Feasible Socialism: Market or Plan or Both. - URL: http://www.whatnextjournal.org.uk/Pages/Ratner/Feassoc.pdf. - URL:

19. Iskandar. Capitalism paradigm shift in the practice of organizational human resource management // RJOAS. 2017. No.4 (64). P. 35-41. - URL: https://doi.org/10.18551/rjoas.2017-04.05

20. Iskenderov R., Gulaliyev M., Nasirova O. Assessment of major factors of food security. URL: https://rjoas.com/issue-2016-10/article_15.pdf

21. Prilukov A.N. Regional mining and minerals usage in market reforms conditions. Vladivostok: Dalnauka, 1998. $156 \mathrm{p}$.

22. Anatoli Prilukov. Peculiarities of mineral resources management systems in liberal and multistructural economies // Proceedings of the 11-th International Multidisciplinary Scientific Geoconference SGEM-2011, 20-25 June, 2011, Bulgaria. Vol.1. P. 877-884.

23. Prilukov A.N. Plan and market models interaction in mining industries of the World's and national economics // Reports of the V Russian Symposium on Economic Theory. Vol.1. - Yekaterinburg: 2012. P. 223-225.

24. Prilukov A.N. Interaction of plan and market-oriented models in the mining industries of the Far Eastern regional and national economies. - URL: http://dropdoc.ru/doc/120562/;doc

25. Prilukov A.N. Will Russia Emerge as Mineral-Resources-Management Country? // ECO. 2014. No.6 (480). P. 82-96.

26. Prilukov A.N. Mineral resources management concept as market reincarnation of traditional Russian professional attitude toward exploration and mining operations. URL: http://giab-online.ru/files/Data/2016/2/Content_Eng.pdf

27. Prilukov A.N. Historic essay on ideas concerning emergence and development of effective mineral resources management. http://www.modernsciencejournal.org/release/USNO_2016_12_4_tom.pdf

28. Prilukov A.N., Sekisov G.V., Litvintsev V.S. Natural resources effective management as sphere of socio-economic development and research area. - URL: https://doi.org/10.18551/rjoas.2017-02.10

29. Prilukov A.N. Effective husbandry of mineral resources - a myth or reality? // - URL: http://eee-region.ru/article/4930/

30. Prilukov A.N. Cataloguing of economy's resource branches in rubricators and abstract databases. - URL: https://doi.org/10.18551/rjoas.2017-01.05

31. PJSC "MMC Norilsk Nickel". Annual Reports. - URL: http://www.nornik.ru/en/investorrelations/annual-reports/annual-reports

32. Chen Qiang. Innovative economy and its state regulation in the China's People Republic. - URL: http://www.pac.by/nfiles/000285_884855_Chen.pdf 